\title{
The Effect of Employee Satisfaction, Organizational Commitment, Organizational Citizenship Behavior on Employee Performance at the Department of Public Works and Spatial Planning of the Bukittinggi City
}

\author{
Ronny Kurniawan ${ }^{1}$, Bahrudin $^{2}$, Salman Hafiz ${ }^{3}$ Mardiah Hadayanti ${ }^{4}$, Anne Putri ${ }^{*}$ \\ ${ }^{12345}$ Magister of Management, Sekolah Tinggi Ilmu Ekonomi H Agus Salim, Bukittinggi, Indonesia
}

\begin{abstract}
The purpose of this study was to analyze the effect of job satisfaction, organizational commitment, Organizational Citizenship Behavior (OCB) on employee performance. The sample consisted of 63 employees at the Bukittinggi City Public Works and Spatial Planning Office. The sampling technique used in this study is total sampling. The analysis technique used was IBM SPSS 20. Job Satisfaction (X1) has a positive effect on Employee Performance (Y) in the Public Works and Spatial Planning Agency in Bukittinggi City. Organizational commitment (X2) and Organizational Citizenship Behavior (OCB) impact negatively on employee performance (Y) at the Department of Public Works and Spatial Planning of Bukittinggi.
\end{abstract}

Keywords:- Job Satisfaction; Organization Commitment; Organizational Citizenship Behavior; and Employee Performance.

\section{INTRODUCTION}

Based on the Regulation of the Mayor of Bukittinggi Number 57 year 2016 regarding the Position, Organizational Structure, Duties and Functions and Work Procedures of the Public Works and Spatial Planning of the Bukittinggi City, it is explained that the task of the Public Works and Spatial Planning Office of Bukittinggi is to carry out regional government affairs in the field of work general and spatial planning and land based on the principle of autonomy and assistance tasks as mandated by Law Number 23 of 2014.

Qualified employees are official assets in the face of increasingly fierce competition today. Because of this can improve the performance of each agency or organization.

Organizational Citizenship Behavior (OCB) is important because if an employee works professionally and voluntarily with a strong sense of belonging to the organization can help his colleagues without coercion then his tasks will be completed properly. If OCB can be applied into organizational culture, it will greatly support the achievement of organizational goals. Besides OCB, there are various factors that influence employee performance such as commitment and job satisfaction. An employee who has a high level of commitment tends to be loyal and wants to stay in the organization.
Employee performance plays an important role for the Office of Public Works and Spatial Planning because each Local Government Work Unit is required to prepare a Government Agency Performance Report. This Report on Accountability and Performance of Government Institutions is a form of responsibility for the main tasks and functions of the Office of Public Works and Spatial Planning as well as the authority to manage resources and policies entrusted to them based on strategic planning that has been formulated previously.

Performance of the strategic objectives of the Office of Public Works and Spatial Planning namely the improvement in quality and quantity of infrastructure for 2017 and 2018 have not yet reached the targets set. Where for 2017 the realization of the target $72.5 \%$ of the target of $75 \%$ and in 2018 the realization of the target $71.98 \%$ of the target of $76.25 \%$.

Based on observations made by researchers at the Department of Public Works and Spatial Planning, it is known that it turns out that if there are colleagues who do not enter, employees at the Department of Public Works and Spatial Planning are not replacing their colleagues' work wholeheartedly, which indicates that the relatively low OCB (Organizational Citizenship Behavior) so it is interesting to study.

The average performance of employees in the Department of Work and Spatial Planning is still not optimal because it has not reached $100 \%$. This performance figure is related to the improvement of governance employee income allowance, so the benefits received do not reach the maximum value because the performance value does not reach $100 \%$.

Another problem is the existence of a research gap or the findings of previous studies of different which can be seen from the research conducted by Sutrisno, Andi Tri Haryono, and Moch Mukeri Warso (2017) found that job satisfaction has a positive effect on performance, while the results Ratih Wulandari (2018), found that job satisfaction did not have a positive effect on employee performance. 
Research gaps others can be seen from the findings of research conducted by Yoga Putrana, Aziz Fatoni, and Moch Mukeri Warso (2016), found that organizational commitment has a positive impact on performance, while the result of research Tri Bodroastuti and Tjandra Tirtono (2019), committed organization does not affect employee performance.

Another research gap from the findings of research conducted by Roby Sambung (2011) found that OCB has a positive effect on employee performance while Luhur Agung Bowo Leksono (2018) OCB had no significant effect on employee performance.

Based on the background of the problem and the identification of the problem, in this study the research issues can be formulated as follows: (1) What is the effect of Job Satisfaction on Performance in the Public Works Department and Spatial Planning in Bukittinggi?, (2) How does the influence of Organizational Commitment on Performance in the Office of Public Works and Spatial Planning Bukittinggi?, (3) What is the effect of Organizational Citizenship Behavior (OCB) on Performance in the Office of Public Works and Spatial Planning in Bukittinggi City?

\section{$>$ Employee Performance}

Mariman Darto (2014) says that the term performance comes from the word " job performance" or " actual performance" that is the performance or actual achievement achieved by someone in carrying out tasks in accordance with the responsibilities given to him. Flippo (1990: 249) states several elements that can be used in assessing employee performance, namely: (1) Quality of work, consisting of elements of timeliness, accuracy, skills and target accuracy , (2) Work quantity, consisting of outputs that are not only in the form of routine and regular tasks but also urgent tasks , (3) work relations, consisting of changes in work, coworkers and cooperation with colleagues and superiors, (4) work toughness, consisting of loyalty initiatives and adherence to regulations has been established.

According to Yoga Putrana, Aziz Fatoni, and Moch Mukeri Warso (2016) in a journal entitled "The Effect of Job Satisfaction and Organizational Commitment on Organizational Citizenship Behavior (OCB) in Improving Employee Performance", with the result that job satisfaction, organizational commitment, and Organizational Citizenship Behavior (OCB) has a positive effect on employee performance.

\section{Job Satisfaction}

P. Robbins and Judge (2017) suggest job satisfaction is identified with things that are individual. Therefore, the level of satisfaction of each person is different and this happens when several factors are met, namely individual needs and their relationship to the degree of employee preference and dislike.
The indicators used to measure job satisfaction according to Robbins (2017) are: (1) Satisfaction with compensation/salary, is the wages earned by someone is proportional to the work done and equal to the wages received by others in the same position, (2 ) Satisfaction with the work itself, the work provided is considered attractive, provides opportunities for learning for employees as well as opportunities to accept responsibility for work , (3) Satisfaction with promotion, employees have a desire to go ahead and develop as a form of selfactualization so that employees will be satisfied if the organization provides opportunities for growth and promotion to a higher level. (4) Satisfaction of supervisors attitudes, ability of superiors to show interest and attention about employees, provide technical assistance, and the role of superiors in treating employees to influence employee behavior in their daily work, (5) Satisfaction of coworkers, peer service work in interactions between employees affects the level of satisfaction felt by employees.

Hasni Dyah Kurniawati and Amin Wahyudi (2015) with the research title "The Effect of Job Satisfaction and Organizational Commitment on Performance with Organizational Citezenship Behavior as a Variable Moderation", with the result that job satisfaction has a positive effect on performance.

However, according to Ratih Wulandari (2018) in a journal entitled Influence of Job Satisfaction and Organizational Commitment on Employee Performance Mediated by Organizational Citizenship Behavior in Employees of Bmt Bina Insan Mandiri with the result that job satisfaction does not have a positive effect on employee performance.

\section{$>$ Organizational Commitment}

Allen \& Meyer (1997: 26) formulated a definition of organizational commitment that is a psychological construct that is a characteristic of the relationship between organizational members and their organizations that have implications for individual decisions to continue their membership in the organization. Based on this definition members have a commitment to their organization compared to members who do not have organizational commitment.

Allen \& Meyer (1997) divide commitment into three dimensions including: 1. Affective Commitment, is a situation in which employees want to do something for the organization, 2. Normative Commitment, is a state in which there is something they should do to organization 3 . Continuous Commitment is a condition where employees need to do something for the organization.

According to Sutrisno, Andi Tri Haryono, and Moch Mukeri Warso (2017) with the title "The Effect of Job Satisfaction and Organizational Commitment on Employee Performance through Organizational Citizenship Behavior as an intervening variable", with the result that organizational commitment has a positive effect on performance. 
This was not found in a study conducted by Raisa Aribatul and Nenden (2020) in a journal entitled Influence of Job Satisfaction and Organizational Commitment on Employee Performance in Self-Help Housing Stimulant Assistance (BSPS) Magelang District Communities in Islamic Perspective with the result that organizational commitment variables have influence significant negative effect on employee performance.

\section{> Organizational Citizenship Behavior (OCB)}

Organ (2003) defines OCB as a special type of work habits that defines individual behavior which is very beneficial to the organization and is freedom of choice, indirectly or explicitly recognized by the formal reward system.

Organ (2003) states that there are five dimensions of OCB, namely (1) Altruism, which is the behavior of helping other employees without coercion on tasks that are closely related to organizational operations, (2) Civic virtue, namely behavior that shows voluntary participation and support for organizational functions both professionally and socially naturally , (3) Conscientiousness is a behavior that contains the performance of employees from the prerequisites of roles that exceeds the minimum standard, (4) Sportsmanship contains about abstinence to make issues that are destructive despite feeling annoyed, (5) Courtesy is behavior to relieve problems related to work faced by others.

Yoga Putrana, Aziz Fatoni, and Moch Mukeri Warso (2016) in a journal entitled "The Effect of Job Satisfaction and Organizational Commitment on Organizational Citizenship Behavior (OCB) in Improving Employee Performance", with the result that job satisfaction, organizational commitment, and Organizational Citizenship Behavior (OCB) has a positive effect on employee performance.

However, it is different from the research conducted by Luhur Agung Bowo Leksono (2018) in a journal entitled The Effect of Organizational Citizenship Behavior (OCB) and Quality of Work Life (QWL) on Employee Performance (Case Study on PT Sumber Jaya Embroidery Employees), with OCB results do not have a significant effect on employee performance.

\section{$>$ Research Conceptual Framework}

Based on the background and theoretical basis previously stated, a research conceptual framework was formulated as follows:

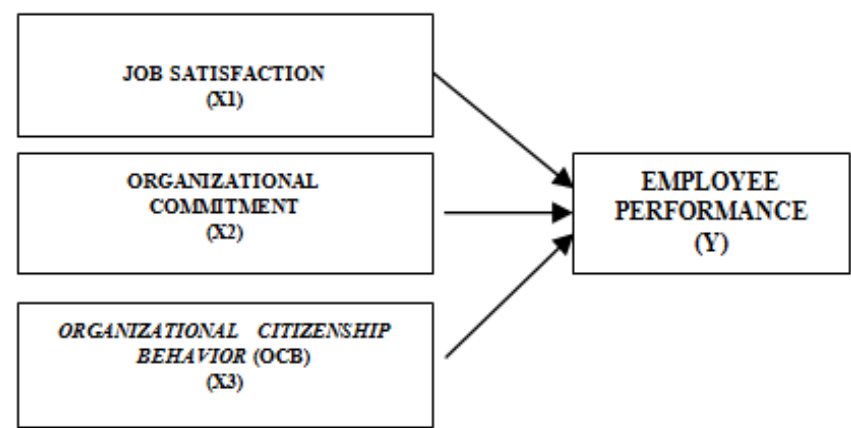

Fig 1:- Research Conceptual Framework

\section{$>$ Hypothesis}

Based on the conceptual framework above, the researcher's hypothesis of the problem is formulated as follows:

H1: Job satisfaction affects employee performance at the Office of Public Works and Spatial Planning of Bukittinggi City.

$\mathrm{H} 2$ : Organizational commitment influences employee performance at the Public Works and Spatial Planning Office in Bukittinggi.

H3: Organizational Citizenship Behavior (OCB) affects employee performance at the Public Works and Spatial Planning Agency in Bukittinggi.

\section{RESEARCH METHOD}

This type of research uses quantitative methods with survey research. The population in this study is the total number of employees at the Public Works and Spatial Planning Office of Bukittinggi with 63 employees. While the number of samples analyzed were all employees at the Public Works and Spatial Planning Agency of Bukittinggi City (census) as many as 63 people consisting of echelon III officials as many as 5 people, echelon IV officials as many as 13 people and implementing positions as many as 45 people, so that all members the population has the same opportunity to become a sample member.

The study was conducted in the form of a crosssectional study in which the study was carried out for 1 (one) month starting from 01 to 30 May 2020 in the Regional Work Unit of the Public Works Agency and Spatial Planning of Bukittinggi City.

In this study the variables independent of her is Job Satisfaction $\left(\mathrm{X}_{1}\right)$ with an indicator variable salary work itself, promotion , the attitude of bosses, and partner work , variable Organizational Commitment $\left(\mathrm{X}_{2}\right)$ with variable indicator commitment of affective, commitment of normative, commitment of continuant, variable Organizational Citizenship Behavior (OCB) ( X3) with variable indicator courtesy, altruism, conscientiousness, civic virtue, sportmanship, while variable dependent it is employee performance $(\mathrm{Y})$ with variable indicator quality of work, quantity of work , an association of work, and work toughness. 
Data collection techniques used in this study were questionnaires. The measurement scale used in this study is the linkert scale which is an ordinal measure where the scale has characteristics related to increased reliability and validity. Test validity according Sugiyono (2016: 177) shows the degree of accuracy of the data actually happened on the object with data collected by the researchers to look for the validity of an item, the item scores correlate with the total of these items. As for the reliability test, to determine the level of reliability of the questionnaire is done by comparing and looking at the Cronbach's alpha coefficient (Ghozali, 2005).

The statistical analysis tool used in this study is multiple regression analysis it is necessary to test the assumptions required in the multiple regression analysis to meet the BLUE (Best Linear Unlimited Estimate) criteria as suggested by Gurajati (2003).

Normality test using the Test Kolmogorov Smirnov with a significance level of 0.05 . The basis of decision making from the test is stated to be normally distributed if the level of significance is greater than 0.05 ( $p>0.05)$.

Linearity test is done to see how the variable $(\mathrm{X})$ affects variable (Y), either influence or inversely proportional. In determining whether the regression equation function that is used linearly, the technique used is deviation from linearity. If the value of linearity is more than $5 \%$, then the regression model can be stated linear.

Multicollinearity test according Gurajati (2003) by looking at the value of the tolerance value or Variance Inflation Factor (VIF). If the VIF value is not more than 10 and the tolerance value is not less than 0.1 , then it can be said to be free from multicollinearity.

According Ghozali (2005), heteroscedasticity test aims to test whether the regression model occurred inequality variance of the residuals of the observations to other observations. Testing of presence and absence of symptoms heteroscedasticity test wear methode Glejser test Where the provisions in this test, if the probability is less than $5 \%$, then heteroscedasticity occurs.

To find out the variables that influence between Job Satisfaction $\left(\mathrm{X}_{1}\right)$, Organizational Commitment $\left(\mathrm{X}_{2}\right)$, and Organizational OCB variables on Performance (Y) individually (partial), the $\mathrm{t}$ test was used. According Ghozali (2005), the basis for decision making for hypothesis is if the significance value (sig) or a probability value (probability) smaller than the significant level $\alpha=$ 0.05 , it can be concluded that there is significant influence of the independent variables on the dependent variable.

To test whether the variables include job satisfaction $\left(\mathrm{X}_{1}\right)$, organizational commitment $\left(\mathrm{X}_{2}\right)$, and Organizational Citizenship Behavior (OCB) $\left(\mathrm{X}_{3}\right)$ simultaneously (simultaneously) affect employee performance (Y), then the F test was used. Or by Ghozali (2005), the basic decision making on ANOVA test or F test is If significance value (sig) or a probability value (probability) smaller than the significant level $\alpha=0.05$, it can be concluded that there is significant influence from the independent variable to the dependent variable.

The coefficient of determination $\left(\mathrm{R}^{2}\right)$ describe the contribution of impact that the independent variable on the dependent variable or to predict and to see how big the contribution of independent variables influence given simultaneously or together on the dependent variable. The coefficient of determination $\left(\mathrm{R}^{2}\right)$ equal to 0 , then there is nothing of influence given the percentage contribution of independent variables on the dependent variable. Conversely, if the coefficient of determination $\left(\mathrm{R}^{2}\right)$ is close to 1 , then the percentage contribution of influence given the independent variable on the dependent variable was perfect, or independent variables used in the study explain $100 \%$ of the variation of dependent variables.

\section{RESULT}

\section{Descriptive analysis of respondents}

General description of the characteristics of respondents in this study was measured based on 4 (four) categories, namely gender, age, position, and years of service. The following characteristics of research respondents are presented in the table below:

\begin{tabular}{|c|c|c|c|}
\hline Profile & Category & Amount & $(\mathbf{\%})$ \\
\hline \multirow{3}{*}{ Gender } & Male & 41 & 65.1 \\
\cline { 2 - 4 } & Female & 22 & 34.9 \\
\hline \multirow{3}{*}{ Age } & $24-34$ years & 8 & 12.7 \\
\cline { 2 - 4 } & $35-45$ years & 39 & 61.9 \\
\cline { 2 - 4 } & $>46$ years & 16 & 25.4 \\
\hline \multirow{3}{*}{ Position } & $\begin{array}{c}\text { Secretary/head of } \\
\text { Division }\end{array}$ & 5 & 7.9 \\
\cline { 2 - 4 } & Head of Sub Division & 13 & 20.6 \\
\cline { 2 - 4 } & Staff & 45 & 71.4 \\
\hline \multirow{2}{*}{$\begin{array}{c}\text { Years of } \\
\text { Service }\end{array}$} & < 5 years & 22 & 34.9 \\
\cline { 2 - 4 } & 5 - 10 years & 2 & 3.2 \\
\cline { 2 - 4 } & $>10$ years & 39 & 25.4 \\
\hline
\end{tabular}

Table 1:- Characteristics of Research Respondents $(\mathrm{n}=63)$ Source: Primary data processed by the author of 2020

Descriptive analysis of respondents is the most gender of respondents is male where the number of male respondents is as many as 41 people $(65.1 \%)$ and the number of women as many as 22 people $(34.9 \%)$. The most types of respondent education were techniques as many as 35 people $(55.6 \%)$, and the least were social as many as 1 person $(1.6 \%)$. The most positions were staff positions of 45 people $(71.4 \%)$ with the most length of office being $>10$ years totaling 39 people $(61.9 \%)$. Age responden most with a lifespan of 35-45 years as many as 39 people $(61.9 \%)$. 
ISSN No:-2456-2165

Description of Research Results

In general, the results of this study can be seen in the following table:

\begin{tabular}{|c|c|c|c|}
\hline Variable & Average & TCR & Information \\
\hline $\begin{array}{c}\text { Employee } \\
\text { Performance }\end{array}$ & 4.15 & 83.03 & Well \\
\hline $\begin{array}{c}\text { Job } \\
\text { satisfaction }\end{array}$ & 3.77 & 75.37 & Pretty good \\
\hline $\begin{array}{c}\text { Organizational } \\
\text { Commitment }\end{array}$ & 3.73 & 74.60 & Pretty good \\
\hline OCB & 3.86 & 77.14 & Pretty good \\
\hline
\end{tabular}

Table 2:- Variable Descriptive Analysis

Source: Primary data processed by the author of 2020

From table 2 above it can be seen that the results of descriptive analysis for each of the variables in this study were obtained:

- The average score of the performance variables of Bukittinggi City Public Works and Spatial Planning staff is 4.15 with a respondent achievement level (TCR) of $83.03 \%$. This shows that the performance of Bukittinggi City Public Works and Spatial Planning employees is in the good category.

- The average score of the job satisfaction variables of the Bukittinggi City Public Works and Spatial Planning Department was 3.77 with a respondent achievement level (TCR) of $75.37 \%$. This shows that the work satisfaction of the Office of Public Works and Spatial Planning is included in the quite good category.

- The average value of organizational commitment variables in the Public Works and Spatial Planning of Bukittinggi City was 3.73 with a respondent achievement level (TCR) of $74.60 \%$. This shows that the organizational commitment of the Bukittinggi City Public Works and Spatial Planning Office is quite good.

- The average value of the Organizational Citizenship Behavior (OCB) variable of the Public Works and Spatial Planning of Bukittinggi City is 3.86 with a respondent achievement level (TCR) of $77.14 \%$. This shows that the Organizational Citizenship Behavior (OCB) of the Office of Public Works and Spatial Planning of Bukittinggi is included in the quite good category.

\section{Validity Test}

In this study using Pearson moment product analysis. Item indicators valid characterized by the correlation between the items of each item question with a score total. According to Sugiyono (2016), the minimum requirement to be considered a valid question item is a valid index value if the item correlation coefficient question exceeds 0,3 $\left(\mathrm{r}_{\text {count }}>0.3\right)$, it is considered to have been valid. Here are the results of testing the validity of each variable independently and variable dependent:

\begin{tabular}{|c|c|c|c|}
\hline $\begin{array}{c}\text { Item No } \\
\text { Statement }\end{array}$ & $\begin{array}{c}\mathbf{R} \text { value } \\
\text { calculated }\end{array}$ & $\begin{array}{c}\text { The } \\
\text { value of } \\
r \text { is } \\
\text { critical }\end{array}$ & Information \\
\hline Performance1 & 0.616 & 0.3 & Valid \\
\hline Performance 2 & 0.570 & 0.3 & Valid \\
\hline Performance 3 & 0.544 & 0.3 & Valid \\
\hline Performance4 & 0.495 & 0.3 & Valid \\
\hline Performance5 & .486 & 0.3 & Valid \\
\hline Performance6 & 0.523 & 0.3 & Valid \\
\hline Performance7 & 0.644 & 0.3 & Valid \\
\hline Performance 8 & 0.475 & 0.3 & Valid \\
\hline Performance9 & 0.612 & 0.3 & Valid \\
\hline Satisfaction1 & 0.440 & 0.3 & Valid \\
\hline Satisfaction & 0.561 & 0.3 & Valid \\
\hline Satisfaction3 & 0.516 & 0.3 & Valid \\
\hline Satisfaction4 & 0.561 & 0.3 & Valid \\
\hline Satisfaction5 & 0.593 & 0.3 & Valid \\
\hline Satisfaction6 & .346 & 0.3 & Valid \\
\hline Satisfaction7 & 0.575 & 0.3 & Valid \\
\hline Satisfaction 8 & 0.562 & 0.3 & Valid \\
\hline Satisfaction9 & 0.428 & 0.3 & Valid \\
\hline Satisfaction 10 & 0.592 & 0.3 & Valid \\
\hline $\begin{array}{l}\text { Organizational } \\
\text { Commitment } 1\end{array}$ & 0.575 & 0.3 & Valid \\
\hline $\begin{array}{l}\text { Organizational } \\
\text { Commitment } 2\end{array}$ & .454 & 0.3 & Valid \\
\hline $\begin{array}{l}\text { Organizational } \\
\text { Commitment } 3\end{array}$ & 0.618 & 0.3 & Valid \\
\hline $\begin{array}{l}\text { Organizational } \\
\text { Commitment } 4\end{array}$ & .672 & 0.3 & Valid \\
\hline $\begin{array}{l}\text { Organizational } \\
\text { Commitment5 }\end{array}$ & 0.844 & 0.3 & Valid \\
\hline $\begin{array}{l}\text { Organizational } \\
\text { Commitment6 }\end{array}$ & 0.764 & 0.3 & Valid \\
\hline OCB1 & 0.640 & 0.3 & Valid \\
\hline OCB2 & .652 & 0.3 & Valid \\
\hline OCB3 & 0.604 & 0.3 & Valid \\
\hline OCB4 & .653 & 0.3 & Valid \\
\hline OCB5 & 0.580 & 0.3 & Valid \\
\hline OCB6 & 0.589 & 0.3 & Valid \\
\hline OCB7 & 0.712 & 0.3 & Valid \\
\hline OCB8 & 0.577 & 0.3 & Valid \\
\hline OCB9 & 0.547 & 0.3 & Valid \\
\hline OCB10 & .851 & 0.3 & Valid \\
\hline
\end{tabular}

Table 3:- Validity Test Results

Source: Primary data processed by the author of 2020

From table 3 in the above, obtained results of testing the validity of the variable employee performance, job satisfaction, organizational commitment, Organization Citizenship Behavior (OCB) are all valid because more substantial than the value of $r$ critical 0.3 . 
Reliability Test

Testing reliability performed by using a formula Croncbach's Alpha. The basis for taking Croncbach's Alpha reliability test according to Ghozali (2005) is the questionnaire is said to be reliable if the Cronbach alpha value $>0.6$. The results of the reliability analysis of each item of the research statement note that the Croncbach's Alpha coefficient value of each variable is as follows:

\begin{tabular}{|c|c|c|c|c|}
\hline No & Variable & Number of Items & Croncbach's Alpha & Information \\
\hline 1 & Employee Performance & 9 & 0.711 & Reliable \\
\hline 2 & Job Satisfaction & 10 & 0.690 & Reliable \\
\hline 3 & Organizational Commitment & 6 & 0.726 & Reliable \\
\hline 4 & $\begin{array}{c}\text { Organizational Citizenship } \\
\text { Behavior (OCB) }\end{array}$ & 10 & 0.841 & Reliable \\
\hline
\end{tabular}

Tabel 4:- Reliability Test Results

Source: Primary data processed by the author of 2020

From the results of the table above the reliability test uses statistical tests . Croncbach's Alpha $(\alpha)$, showed that all the variables that are used in the research is that the variables Performance Employees (Y), Satisfaction Work (X1), Commitment Organization (X2), and Organizational Citizenship Behavior (X3) has a value of Cronbach's Alpha> 0,60 . It is shown that all the answers of respondents already consistent in answering any items that measure each - each variable

\section{Multiple Linear Regression Analysis Test}

Based on the results of calculations using a computer using the IBM SPSS for Windows Ver. 20.0. The results can be seen in the following table:

\begin{tabular}{|c|c|c|c|}
\hline Variable & $\begin{array}{c}\text { Coef. } \\
\text { Regression }\end{array}$ & $\mathbf{t}_{\text {count }}$ & Sig. \\
\hline Constant & 48,632 & & \\
\hline Job Satisfaction &, 532 & 6,751 &, 000 \\
\hline $\begin{array}{c}\text { Organizational } \\
\text { Commitment }\end{array}$ &,- 399 & $-3,602$ &, 001 \\
\hline $\begin{array}{c}\text { Organizational } \\
\text { Citizenship } \\
\text { Behavior }\end{array}$ &,- 580 & $-8,259$ &, 000 \\
\hline $\mathbf{F}$ count $=30,838$ & Sig. ,000 & & \\
\hline $\mathbf{R}^{2}=0,611$ & & & \\
\hline
\end{tabular}

Table 5:- Recap of Multiple Regression Analysis Test Results

Source: Primary data processed by the author of 2020

From table 5 above, the regression equation model for the effect of Satisfaction Work, Commitment Organization, and Organizational Citizenship Behavior Regency employees is as follows:

\section{$Y=48,632+0.532 X_{1}-0.399 X_{2}-0.580 X_{3}+e$}

From the regression equation above, it can be interpreted as follows the constant value $(\alpha)$ is 48.632 meaning that without the effect of Satisfaction Work, Commitment Organization, and Organizational Citizenship Behavior already exists at $48.63 \%$.

The regression coefficient value of the job satisfaction variable (b1) is 0.532 , which means that for every increase in one value of job satisfaction, employee performance increases by 0.532 . Another case with the regression coefficient value of the organizational commitment variable (b2) is -0.399 which means that for every increase in one value of organizational commitment, employee performance decreases by 0.399 . Likewise with the Organizational Citizenship Behavior (OCB) regression coefficient (b3) value of $-0,580$ which means that for every increase in one Organizational Citizenship Behavior (OCB) value, employee performance decreases by 0.58 .

\section{Partial Test ( $t$ Test)}

Statistical tests are used to show how far the influence of one in dependent variable individually in explaining the dependent variable.

Under the table 5 at the top. It is known that the value of the significance of the variable Satisfaction Work (X1) against Performance (Y) of 0.000 , variable Commitment Organization (X2) against Performance (Y) of 0.001, and the variable OCB (X3) against Performance (Y) equal to 0.000. According to Ghozali (2005), if the value Sig <0.005 then means that the variable independent $(\mathrm{X})$, as a partial effect on the variable dependent (Y). Then it is concluded that the test $\mathrm{t}$ partially on top of that variable Satisfaction Work (X1) effect on the variable Performance (Y), variable commitment of the Organization effect on variable Performance (Y), and a variable Organizational Citizenship bahavior (OCB) (X3) influence on the variable Performance (Y) at the Bukittinggi City Public Works and Spatial Planning Office.

When compared between the value of tcount with $t$ table, where the $\mathrm{t}$ table value is equal to $2.001(\mathrm{t}=\alpha / 2: \mathrm{n}-\mathrm{k}-$ $1)=(0.05 / 2): 63-3-1)=(0.025: 59)$. Then the results of this study are obtained that for the variable Job Satisfaction (X1) with a t count of 6.751 is greater than 2.001. This means that the variable Job Satisfaction (X1) has a positive effect on performance (Y). Organizational Commitment Variable (X2) with a calculated t value of -3.602 is greater than - 2.001. This means that the Organizational Commitment Variable (X2) has a negative effect on Performance (Y). As for the Organizational Citizenship Bahavior (OCB) variable with a calculated $t$ value of 8.259 , it is greater than -2.001 . This means that the Organizational Citizenship Bahavior Variable (OCB) (X3) has a negative effect on Performance (Y). 


\section{$>$ Simultaneous Test (F Test)}

From the calculated $\mathrm{F}$ value compared with the $\mathrm{F}$ value of $2.76(\mathrm{k}: \mathrm{n}-\mathrm{k})=(3: 60)$. It was found that the $\mathrm{F}$ count of 30.838 was greater than the $\mathrm{F}$ table value of 2.76 . Besides that, from ANOVA test or F test, the significance value is 0,000 . Because the probability or significance is far less than 0.05 and the value of $F$ arithmetic $>F$ table, then the regression model can be used to predict job satisfaction variables, organizational commitment and Organizational Citizenship Behavior (OCB) together affecting the performance of employees in the Office Public Works and Spatial Planning of Bukittinggi City.

\section{$>$ Determination Coefficient Test $\left(R^{2}\right)$}

The coefficient of determination is useful for measuring how much the ability of independent variables in describing the dependent variable. Value of coefficient determination is an tare zero and one. If the value is getting closer to one then the ability of the model in explaining the dependent variable is higher.

The analysis result coefficient determination $\left(\mathrm{R}^{2}\right)$ known value of $R$ Square of 0,611 . The relationship will be perfect if $(100 \%)$ or near perfect if there are other independent variables included in the study. Figures that concluded that the variable job satisfaction (X1), organizational commitment (X2), and Organizational Citizenship Behavior (OCB) (X3) are simultaneously or jointly effect on the variable employee performance $(\mathrm{Y})$ by $61 \%$, while $39 \%$ is explained by another variable.

\section{CONCLUSION}

\section{A. Conclusions}

Based on the results of testing the hypotheses and findings in the previous chapter, "The Effect of Job Satisfaction, Organizational Commitment, Organizational Citizenship Behavior (OCB) on Employee Performance in the Public Works Department and Spatial Planning of Bukittinggi City" can be concluded as follows:

$>$ Job Satisfaction (X1) has a positive effect on Employee Performance (Y) in the Public Works and Spatial Planning Agency in Bukittinggi City. Based on the value of $t$ count is 6.751 is greater than $t$ table amounted to 2.001, meaning that job satisfaction ( $\mathrm{X} 1$ ) partially affect the variable employee performance $(\mathrm{Y})$.

$>$ Organizational commitment (X2) impact negatively on employee performance (Y) at the Department of Public Works and Spatial Planning of Bukittinggi . Based on the $t_{\text {count }}$ value is - 3.602 greater than $t_{\text {table }}$ of - 2.001, meaning that Organizational Commitment (X2) partially influences the Employee Performance variable (Y).

$>$ Organizational Citizenship Behavior (OCB) (X3) has a negative effect on Employee Performance (Y) in the Public Works and Spatial Planning Agency in Bukittinggi City . Based on the $t_{\text {count }}$ value is $-8,259$ is greater than $t_{\text {table }}$ of - 2,001, meaning that Organizational Citizenship Behavior (OCB) ( X3 ) partially influences the Employee Performance variable (Y).

\section{B. Suggestions}

Based on the research findings and conclusions, the authors propose the following suggestions:

$>$ From the results of the study, when viewed from the results of the TCR values it was found that the TCR values for job satisfaction, organizational commitment, and Organizational Citizenship Behavior (OCB) of the Public Works Department and Spatial Planning of Bukittinggi City in the category were quite good. This shows that the need for maximum attention by the leadership of job satisfaction , organizational commitment, and Organizational Citizenship Behavior (OCB) so that the implementation of employee work can realize the vision and mission of the Office of Public Works and Spatial Planning of Bukittinggi City.

$>$ From the result, when viewed from the organizational commitment (X2) impact negatively on employee performance (Y) at the Department of Public Works and Spatial Planning of Bukittinggi is expected that their implementation management system that is better to improve the organization's commitment to self employee.

$>$ Organizational Citizenship Behavior (OCB) ( X3 ) has a negative effect on Employee Performance (Y) in the Public Works and Spatial Planning Office in Bukittinggi. It is expected to improve OCB , one of the interventions that can be carried out is cooperation with the collaboration training method.

$>$ From the results of the study, when viewed from the coefficient of determination, there are still other variables not included in this study that affect employee performance. Therefore, in order to improve employee performance, it is expected that the leadership will provide more opportunities for employees to attend the Training, Workshop, and other formal education to improve employee competence. In addition, it is also hoped that the leadership will begin to dig up information from all levels of employees on the implementation of work and also the expectations of employees for the future. It is intended that the performance of the Public Works and Spatial Planning Office in Bukittinggi can be improved and maximized.

\section{REFERENCES}

[1]. Agung B. L, Luhur, The Effect of Organizational Citizenship Behavior (OCB) and Quality of Work Life ( QWL ) on Employee Performance (Case Study on Employees of PT Sumber Jaya Embroidery), Jakarta: Syarif Hidayatullah State Islamic University, 2018.

[2]. Allen \& Meyer. Commitment in the Workplace (Theory, Research and Application). Sage Publication London, 1997.

[3]. Bodroastuti , Tri and Tjandra Tirtono, The Effect of Organizational Commitment and Job Satisfaction on Organizational Citizenship Behavior (OCB) and Its Impact on Employee Performance (Study of PT Semarang Multi Terminal Indonesia Employees), Semarang: Widya Manggala College of Economics. 2019. 
[4]. Bodroastuti, Tri and Argi Ruliaji, The Effect of Organizational Commitment and Job Satisfaction on Organizational Citizenship Behavior (OCB) and Its Impact on Employee Performance (Study of Employees of PT. Ritra Cargo Indonesia, Central Java Branch), Semarang: Widya Manggala College of Economics, 2016.

[5]. Darto, Mariman , The Role of Organizational Citizenship Behavior (OCB) in Improving Individual Performance in the Public Sector, 2014.

[6]. Dyah Kurniawati, Hasni and Wahyudi, Amin, Effect of Job Satisfaction and Organizational Commitment on Performance with Organizational Citezenship Behavior as Moderation Variables (Study of Hospital Employees in Karanganyar District ), Surakarta: Slamet Riyadi University Surakarta, 2015.

[7]. Flippo, Edwin B. Indonesian Edition Personnel Management Printed 2 . Jakarta: Erlangga, 1990.

[8]. Ghozali , Imam, Application of Multivariate Analysis with SPSS, Semarang: Diponegoro University, 2005.

[9]. Performance Report of Government Agencies Public Works and Spatial Planning Office City of Bukittinggi, Bukittinggi: DPUPR, 2017.

[10]. Performance Report of Government Agencies Public Works and Spatial Planning Office City of Bukittinggi, Bukittinggi: DPUPR, 2018.

[11]. Organ, Dennis W, Organizational Citizenship Behavior. Its Nature, Antecendents, and Consequences, California : Sage Publications, Inc. , 2003.

[12]. Putrana, Yoga, et . Al, The Effect of Job Satisfaction and Organizational Commitment on Organizational Citizenship Behaviorin Improving Employee Performance (Study of PT. Gelora Persada Mediatama Semarang's employees ), Semarang: Pandanaran University Semarang, 2016.

[13]. Robbins, Stephen P. And Timothy A. Judge, Organizational Behavior Sixteenth Edition, Salemba Empat Publisher: Jakarta, 2017.

[14]. Sambung, Roby, The Effect of Job Satisfaction, Organizational Commitment, Personality, and Professionalism of Lecturers on Organizational Citizenship Behavior and Its Impact on Lecturer Performance (Studies at Palangkaraya University), Palangkaraya: Palakangkaraya University , 2011.

[15]. Sugiyono, Quantitative, Qualitative and R\&D Research Methods . Bandung: PT Alfabet, 2016.

[16]. Sutrisno, et . Al, The Effect of Job Satisfaction and Organizational Commitment on Employee Performance through Organizational Citizenship Behavior (OCB) as Intervening Variables ( Study on Employees of PT. Fumira Semarang), Semarang: Pandanaran University Semarang, 2017.

[17]. Wulandari, Ratih, The Effect of Job Satisfaction and Organizational Commitment on Employee Performance Mediated by Organizational Citizenship Behavior on BMT Bina Insan Mandiri Employees , Surakarta: Surakarta State Islamic Institute. 2018. 